International Journal of Life Sciences
Available online at http://sciencescholar.us/journal/index.php/ijls
Vol. 2 No. 1, April 2018, pages: $21 \sim 28$
e-ISSN: 2550-6986, p-ISSN: $2550-6994$
http://dx.doi.org/10.29332/ijls.v2n1.83

\title{
Growth and Blood Profile of Lepus Nigricollis Fed Diet Fermented Coffee Skin in Different Levels
}

\author{
I Made Nuriyasa a, Eny Puspani ${ }^{\text {b }}$, Wayan Sayang Yupardhi ${ }^{c}$ \\ Article history: Received 8 June 2017, Accepted in revised form 3 January 2018, Approved 5 February 2018, \\ Available online 10 February 2018
}

\section{Correspondence Author a}

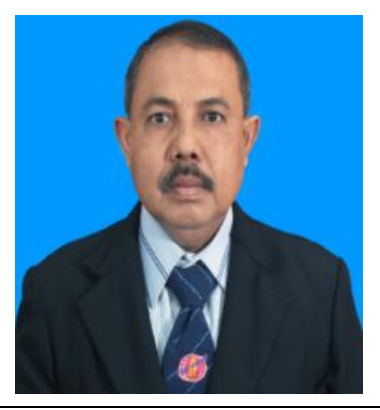

Keywords

Blood profile;

Coffee skin;

Growth rate;

Lepus nigricollis;

Local female rabbit;

\begin{abstract}
The research objective was to know growth and profile of blood of local rabbit (Lepus nigricollis) fed fermented coffee skin in different levels. There were 80 animals used in the research; the design used was Randomized Block Design with five treatments and eight blocks (replicates). Treatments used in the research were a diet without coffee skin called diet control (R0), 10\% coffee skin (R!), 20\% coffee skin (R2), 10\% fermented coffee skin (R3) and 20\% fermented coffee skin (R4). Results of the research showed that erythrocyte and hematocrit of the animals fed diet $\mathrm{R} 3$ were better $(\mathrm{P}<0.05)$ than $\mathrm{R} 4, \mathrm{R} 2$, $\mathrm{R} 1$, and $\mathrm{R} 0$. There were no significant different $(\mathrm{P}<0.05)$ among treatments $\mathrm{R} 0$, $\mathrm{R} 1, \mathrm{R} 2, \mathrm{R} 3$ and R4 to leucocytes of the female animals. Blood cholesterol of the animals fed diet $\mathrm{R} 4$ was the lowest $(\mathrm{P}<0.05)$ than other treatments. The animals fed diet R3 resulted in feed consumption, final body weight (on the age of 17 weeks $)$ and weight gain higher $(\mathrm{P}<0.05)$ thanR4, R2, R1, and R0. The different levels of coffee skin used in the research were not affect significantly feed conversion value. It could be concluded that growth rate and profile of blood of the female animals fed $10 \%$ fermented coffee skin were better than other treatments.
\end{abstract}

e-ISSN : 2550-6986, p-ISSN : 2550-6994@ Copyright 2018. The Author. SS Journals Published by Universidad Técnica de Manabí. This is an open-access article under the CC BY-SA 4.0 license (https://creativecommons.org/licenses/by-sa/4.0/) All rights reserved.

\section{Contents}

Abstract

1. Introduction

2. Research Method 22

3. Results and Analysis

a Faculty of Animal Science, Udayana University, Denpasar, Bali 80232

b Faculty of Animal Science, Udayana University, Denpasar, Bali 80232

c Faculty of Animal Science, Udayana University, Denpasar, Bali 80232 


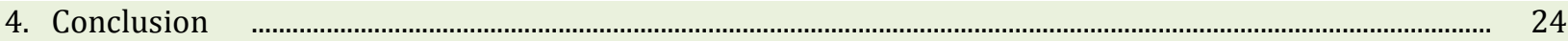

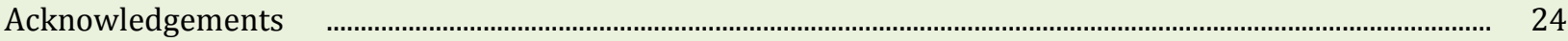

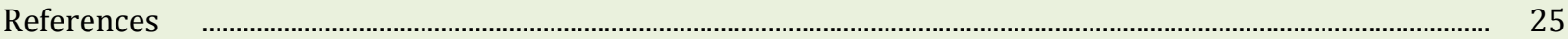

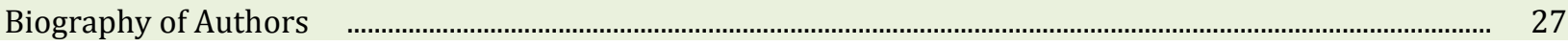

\section{Introduction}

Target to reach animal protein self of Indonesia society in the year of 2014 will facing obstacle if only base on big ruminant (cattle and buffalo) and owning small area and period of production is long-term (Mastika, 2011). Rabbit development is one of the solution to reach acceleration animal protein of the society particularly village society due to the animals need not much area, and capital is small relatively (Nuriyasa et al., 2015). Unsuccessful of farmers for developing rabbit farming is due to farmers knowledge about feed nutrition is still low (Nuriyasa et al., 2016). Using of coffee skin as feed can increase it value. Bio-fermented coffee skin can increases nutritive value of the matter and digestibility coefficient, to help to minimize gas of glass house and to make the farm becomes unpolluted environment (Dubey, 2007).

Availability of coffee skin for 4118.24 ton/ha (in Bali) as an ingredient of the animals feed is very potent. Trough fermentation process with Aspergillus niger the protein content of coffee skin can be increased from $9.94 \%$ to $17.81 \%$, crude fiber content decreased from $18.74 \%$ to13.05\% (Lestari et al., 2005). Studied of Parwati et al. (2008) reported that coffee skin-fermented with Aspergillus niger could replace rice bran that was used as a concentrate to feed cattle. Research results of Muryantho et al. (2006) reported that utilization of $5 \%$ coffee skin was not affected to the performance of endogenous chicken. Gontoro (2004) recommended that level utilization of coffee skin powder for pig and chicken feeds were 10 to $15 \%$. There is no much information yet about the use of fermented coffee skin in research particularly mature female rabbit.

\section{Research Method}

Rabbit

There were 80 local female rabbits with initial weight for $258.50 \mathrm{~g}$ per head used in

the research.

Animal Pen

The research used 40 battery pens where length $=70 \mathrm{~cm}$, wide $=50 \mathrm{~cm}$ and height $=45 \mathrm{~cm}$ each $($ Sceire, 1999). The height of the pens was $70 \mathrm{~cm}$ above the ground.

Feed and Drinking Water

The feed used in the research was composed of some ingredients, i.e., yellow corn, fish mill, rice bran, coconut milk, soybean mill, elephant grass, tapioca mill, coffee skin, fermented coffee skin, coconut oil, and bone mill. Diet fed was same level energy content $(2.500 \mathrm{kcal} / \mathrm{kg})$ and same level crude protein content $(16 \%)$. Drinking water was originally from the water around the pens. Feed and drinking water fed adlibitum

Blood Profile

The observation was conducted only once at the end of the research on the age of the animals was 17 weeks. The animals fasted for 12 hours before blood samples were taken. The blood was taken for six cc on the ear of each animal with a project where it tube was lined with anticoagulant, i.e. lithium heparin (Xiangmei, 2008).

\section{Growth}

Feed and water consumption were calculated once a week where the amount of feed offered to the animals minus the rest at that day. Weighed of body weight was conducted once a week to obtain weight gain. Feed conversion ratio (FCR) was calculated with a comparison between total feed consumed and weight gain during the research.

Data Analysis

Obtained data were analyzed with ANOVA; if it is significantly differences among treatments, the analysis would be continued with Duncan's Multiple Range Test (Steel and Torrie, 1980). 


\section{Results and Analysis}

Table 1 showed that blood of the animals fed diet R3 contained hemoglobin, erythrocyte, and hematocrit higher $(\mathrm{P}<0.05)$ than the R4, R2, R1, and R0. McNitt (1996) reported that hemoglobin, erythrocyte, and hematocrit of blood are the transportation of oxygen in body tissue that needs in metabolism process. The animals fed R3 resulted in the highest weight gain. Nuriyasa et al. (2014) reported that high growth rate level as result of energy retention and high protein caused the process of hemoglobin, erythrocyte, and hematocrit formed in blood are higher. There was no significant different (P $>0.05$ ) to leukocyte content of the local male animals blood fed R0, R1, R2, R3, and R4. Leukocyte content of the animals fed R0, R1, R2, R3, and R4 were 6,74 x $10^{3} / \mu \mathrm{l}, 6,11 \times 10^{3} / \mu \mathrm{l}, 6,03 \times 10^{3} / \mu \mathrm{l}, 5,98 \times 10^{3} / \mu \mathrm{l}$ dan $\mathrm{R} 47,12 \times 10^{3} / \mu \mathrm{l}$ respectively. This showed that the animal fed diet with different levels of coffee skin was no significant difference in stress. This was similar to work of Alhaidary et al. (2010) who found that leukocyte content of the animal blood was about 6.3 to $10 \times 10^{3} / \mu$ l.

Table 1

Blood Profile of Local Female Rabbit Fed Diet in Different Levels of Coffee Skin

\begin{tabular}{lrrrrrr}
\hline \multirow{2}{*}{ Variable } & \multicolumn{7}{c}{ Treatment } \\
\cline { 2 - 7 } & \multicolumn{1}{c}{ R0 } & \multicolumn{1}{c}{ R1 } & \multicolumn{1}{c}{ R2 } & \multicolumn{1}{c}{ R4 } & SEM \\
\hline Hematology Variables & & & & & & \\
Hemoglobin (g/100 & $11,43^{\mathrm{b}}$ & $10,98^{\mathrm{c}}$ & $11,78^{\mathrm{b}}$ & $12,85^{\mathrm{a}}$ & $12,05^{\mathrm{a}}$ & 0,09 \\
dl) & & & & & & \\
Leukocyte$\left(10^{3} / \mu \mathrm{l}\right)$ & $6,74^{\mathrm{a}}$ & $6,11^{\mathrm{a}}$ & $6,03^{\mathrm{a}}$ & $5,98^{\mathrm{a}}$ & $7,12^{\mathrm{a}}$ & 0,36 \\
Erythrocyte $\left(10^{6} / \mu \mathrm{l}\right)$ & $5,57^{\mathrm{b}}$ & $5,07^{\mathrm{c}}$ & $5,44^{\mathrm{b}}$ & $5,84^{\mathrm{a}}$ & $5,65^{\mathrm{a}}$ & 0,02 \\
Hematocryte $(\%)$ & $37,69^{\mathrm{b}}$ & $36,14^{\mathrm{c}}$ & $37,97^{\mathrm{b}}$ & $40,58^{\mathrm{a}}$ & $38,02^{\mathrm{b}}$ & 0,17 \\
$\begin{array}{l}\text { Cholesterol }(\mathrm{mg} / 100 \\
\text { dl) }\end{array}$ & $131,33^{\mathrm{a}}$ & $133,05^{\mathrm{a}}$ & $133,17^{\mathrm{a}}$ & $120,12^{\mathrm{ab}}$ & $88,64^{\mathrm{b}}$ & 3,06 \\
\hline
\end{tabular}

Description:

R0 : diet without coffee skin

R1 : Diet with $10 \%$ unfermented coffee skin

R2 : Diet with $20 \%$ unfermented coffee skin

R3 : Diet with $10 \%$ fermented coffee skin

R4 : Diet with $20 \%$ fermented coffee skin

The same super scrip in the same rows is no significant different $(\mathrm{P}>0.05)$ but, the different super scrip in the same rows is significantly different $(\mathrm{P}<0.05)$.

SEM: Standard Error of The Treatment Means

Table 2

Performance and Carcass of Rabbit Fed Diet with Different Levels of Coffee Skin

\begin{tabular}{lrrrrrr}
\hline \multirow{2}{*}{ Variable } & \multicolumn{7}{c}{ Treatments } \\
\cline { 2 - 7 } & \multicolumn{1}{c}{ R0 } & R1 & R2 & R3 & R4 & SEM \\
\hline Performance and Carcass Variable & & & & & \\
Final body weight (g) & 1744,52 & $1730,13^{\mathrm{b}}$ & $1735,37^{\mathrm{b}}$ & $1878,45^{\mathrm{a}}$ & 1745,71 & 11,7 \\
& $\mathrm{~b}$ & & & & $\mathrm{~b}$ & 4 \\
Feed consumption (g/day) & $76,39 \mathrm{c}$ & $79,63^{\mathrm{b}}$ & $83,47^{\mathrm{b}}$ & $80,63^{\mathrm{b}}$ & $86,55^{\mathrm{a}}$ & 43,4 \\
& & & & & & 6
\end{tabular}

Nuriyasa, I., Puspani, E., \& Yupardhi, W. (2018). Growth and Blood Profile of Lepus Nigricollis Fed Diet Fermented Coffee Skin in Different Levels. International Journal Of Life Sciences (IJLS), 2(1), 21-28. 


\begin{tabular}{lrrrrrr} 
Weight gain (g/day) & $21,47^{\mathrm{b}}$ & $21,32^{\mathrm{b}}$ & $21,03^{\mathrm{b}}$ & $22,99^{\mathrm{a}}$ & $21,01^{\mathrm{b}}$ & 11,1 \\
Feed conversion & $3,56^{\mathrm{b}}$ & $3,73^{\mathrm{b}}$ & $3,96^{\mathrm{a}}$ & $3,51^{\mathrm{b}}$ & $4,12^{\mathrm{a}}$ & 0,03 \\
\hline
\end{tabular}

Description:

R0 : diet without coffee skin

R1 : Diet with $10 \%$ unfermented coffee skin

R2 : Diet with $20 \%$ unfermented coffee skin

R3 : Diet with $10 \%$ fermented coffee skin

R4 : Diet with $20 \%$ fermented coffee skin

The same super scrip in the same rows is no significant different $(\mathrm{P}>0.05)$ but, the different super scrip in the same rows is significantly different $(\mathrm{P}<0.05)$.

SEM: Standard Error of the Treatment Means.

\section{Conclusion}

Cholesterol in the animals blood fed diet R4 was lower $(\mathrm{P}>0.05)$ than the R3 cholesterol that absorbed in the intestine is also decreased (Alhaidary et al., 2010). The animal fed diet R3 rich final body weight and weight gain higher $(\mathrm{P}<0.05)$ than the $\mathrm{R} 4, \mathrm{R} 2, \mathrm{R} 1$, and $\mathrm{R} 0$. This was due to bio-fermentation process in ingredients of diet that could increase its nutritive value (Dubey, 2007). According to Krisnan (2002) that Aspergillus niger could decrease tannin content for $33 \%$, so it could increase feed consumption and energy metabolic significantly. Feed conversion value on the animals fed diet R3 was high er $(\mathrm{P}<0.05)$ compare to others. The animals fed $10 \%$ fermented coffee skin showed that hematology, performance, and carcass better response than others.

\section{Acknowledgements}

The authors would like to thank Government of Indonesia through Department Research and Public Service of Udayana University for their budget supported through Study Program Research Scheme. Thanks also to the Rector of Udayana. University. The Dean of Faculty of Animal Science Udayana University for their facilities research supported. 


\section{References}

1. Alhaidary, A., Mohamed, H. E., \& Beynen, A. C. (2010). Impact of dietary fat type and amount on growth performance and serum cholesterol in rabbits. Am. J. Anim. Vet. Sci, 5(1), 60-64.

View in (Google Scholar)

2. Badarina, I., Evvyernie, D., Toharmat, T., Herliyana, E. N., \& Darusman, I. K. (2013). Nutritive value of coffee husk fermented with Pleurotus ostreatus as ruminant feed. Media Peternakan, 36(1), 58.

View in (Google Scholar)

3. Dubey, R. C. (1993). A textbook of Biotechnology. S. Chand Publishing.

View in (Google Scholar)

4. Guntoro, B., Widyobroto, B. P., Umami, N., Nurtini, S., \& Pertiwiningrum, A. (2016). Marketing and Institutional Characteristics of Dairy Industry In Indonesia. International Journal of Environmental \& Agriculture Research (IJOEAR), 2(3), 106-114.

View in (Google Scholar)

5. Irlbeck, N. A. (2001). How to feed the rabbit (Oryctolagus cuniculus) gastrointestinal tract. Journal of Animal Science, 79(E-Suppl), E343-E346.

View in (Google Scholar)

6. Krishnan, R., \& Maru, G. B. (2004). Inhibitory effect (s) of polymeric black tea polyphenol fractions on the formation of [3H]-B (a) P-derived DNA adducts. Journal of agricultural and food chemistry, 52(13), 4261-4269.

View in (Google Scholar)

7. Kusumayanti, G. D., \& Dewantari, N. M. (2017). The Influence of Low Purine Diet and Physical Activity on Changing of Uric Acid Levels in Hyperuricemia. International Journal of Health Sciences (IJHS), 1(3), 1-9.

View in (Google Scholar)

8. Mastika, I. M., Budiarti, N. L. G., Nuriyasa, I. M., \& Puger, A. W. (2017, March). Growth Performance of Male Rabbits (Lepus negricollis) Fed Different Levels of Fermented Coffee Pulp. In Proceedings of International Seminar on Livestock Production and Veterinary Technology (pp. 489-494).

View in (Google Scholar)

9. Meza, A. K. T., Freyre, J. R. A., Cevallos, M. G. O., \& Pico, M. J. M. (2018). Autonomy, Good Humor and Support Networks, Potential of Community Resilience Intervention in People Victims of the Earthquake in the Calderón Parish. International Research Journal of Management, IT and Social Sciences (IRJMIS), 5(1), 1-8.

View in (Google Scholar)

10. Mustika, I. W., \& Harini, G. A. (2017). Increasing Education of Family Support for Decreasing Depression Level towards Elderly. International Journal of Health Sciences (IJHS), 1(3), 10-16.

View in (Google Scholar)

11. Nahak, S. (2017). Criminal Law Policy on Land Functions Impacting Climate Change in Indonesian National Law Perspective. International Journal of Social Sciences and Humanities (IJSSH), 1(3), 28-39.

View in (Google Scholar)

12. National Research Council. (1977). Nutrient Requirements of Rabbits: 1977. National Academies Press. View in (Google Scholar)

13. Nuriyasa, I. M., Mastika, I. M., \& Dewi, G. A. M. K. (2015). Performance of local rabbit (Lepus nigricollis) fed diets containing different level of fermented coffee pulp. African Journal of Agricultural Research, 10(52), 4820-4824. View in (Google Scholar)

Nuriyasa, I., Puspani, E., \& Yupardhi, W. (2018). Growth and Blood Profile of Lepus Nigricollis Fed Diet Fermented Coffee Skin in Different Levels. International Journal Of Life Sciences (IJLS), 2(1), 21-28. 
14. Nuriyasa, I. M., Mastika, I. M., Mahardika, G. D., Kaqsa, I. W., \& Aryani, I. G. A. G. (2014). Energy and protein retention of local rabbit housed in different cages. J Biol Chem Res, 31, 800-807.

View in (Google Scholar)

15. Nuriyasa, I. M., Yupardhi, W. S., \& Puspani, E. Journal of Biological and Chemical Research. View in (Google Scholar)

16. Ogu, G. I., \& Orjiakor, P. I. (2017). Microbiological and Nutritional Qualities of Fermented Melon Seed Shells. International Journal of Life Sciences (IJLS), 1(2), 1-9.

View in (Google Scholar)

17. Parwati, I. A, I.G.A.K. Sudaratmaja, N. W. Trisnawati, P. Suratmini, N. Suyasa, W. Sunanjaya, L.G. Budiari dan Pardi. 2008. Research report of Agriculture system, Tropical dry land at Belanga Village, Bangli Regency, Bali province, Indonesia.

View in (Google Scholar)

18. Prospective Studies Collaboration. (2002). Age-specific relevance of usual blood pressure to vascular mortality: a meta-analysis of individual data for one million adults in 61 prospective studies. The Lancet, 360(9349), 19031913.

View in (Google Scholar)

19. Saxena, A. (2017). The Impact of Nutrition on the Overall Quality of Life Adolescent Girls are Living Across the City of Kota. International Journal of Life Sciences (IJLS), 1(1), 40-48.

View in (Google Scholar)

20. Schiere, J. B. (1999). Backyard Farming in the Tropics. CTA Published.

View in (Google Scholar)

21. Steel, R. G., \& Torrie, J. (1960). Principales And Pricedures Of Statistics. Mcgraw-Hill Book Company, Inc,; New York; Toronto; London.

View in (Google Scholar)

22. Suarjana, N., Karmaya, I. N. M., Satriyasa, B. K., Pangkahila, J. A., \& Astuti, N. P. W. (2017). The Influence of Granting Ngor Eggplant (Solanium Indicum) Extract inhibiting of Spermatogenesis in Mice (Mus Musculus). International Journal of Health Sciences (IJHS), 1(2), 12-19.

View in (Google Scholar)

23. Suiraoka, I. P., Duarsa, D. P. P., Wirawan, I. D. N., \& Bakta, I. M. (2017). Perception of Parents, Teachers, and Nutritionist on Childhood Obesity and Barriers to Healthy Behavior: A Phenomenological Study. International Journal of Health Sciences (IJHS), 1(2), 1-11.

View in (Google Scholar)

24. UK Prospective Diabetes Study (UKPDS) Group. (1998). Intensive blood-glucose control with sulphonylureas or insulin compared with conventional treatment and risk of complications in patients with type 2 diabetes (UKPDS 33). The lancet, 352(9131), 837-853.

View in (Google Scholar)

25. Xiangmei, G. U. A. N. (2008). Rabbit Feed Nutrition Study for Intensive, Large-Scale Meat Rabbit Breeding. Orgnic rabbits production from forages.

View in (Google Scholar) 
Biography of Author

\begin{tabular}{|c|c|}
\hline \multicolumn{2}{|l|}{ Personal Data } \\
\hline Full Name & \\
\hline Place and Date of Birth & : Tabanan, Bali, Indonesia 20 February 1962 \\
\hline Academic Position & : Lecturer (Associate Professor) \\
\hline Faculty & : Animal Science \\
\hline University & : University of Udayana (UNUD) \\
\hline Office Address & $\begin{array}{l}\text { : Jimbaran District, Badung Regency, Indonesia, (0361701772), P.B. } \\
\text { Sudirman Street, Bali, Indonesia (0361222096) }\end{array}$ \\
\hline Ph./Fax & : 0361222096 \\
\hline Home Address & \multirow{2}{*}{$\begin{array}{l}\text { : Sriwijaya Street, N0: 25, Tabanan Regency, Bali, Indonesia. } \\
\text { : } 082237230123 \text { / madenuriyasa@yahoo.com }\end{array}$} \\
\hline Ph./Fax & \\
\hline \multicolumn{2}{|c|}{ Educational Background } \\
\hline $\begin{array}{c}\text { Year of } \\
\text { Graduation }\end{array}$ & Faculty and University \\
\hline 1986 & Faculty of Animal Science \\
\hline 1991 & $\begin{array}{l}\text { Institute of Agriculture (IPB) Animal Nutrition } \\
\text { Bogor, Indonesia }\end{array}$ \\
\hline 2012 & Udayana University \\
\hline
\end{tabular}

Publication Paper

1. I Made Nuriyasa; I Made Mastika, I Gede Mahardika, I Wayan Kasa. 2012. Temperature Humidity Index and Physiological Responses of Local Rabbit Offered Different Level of Energy and Protein Feeds and Housed in Two Cage Systems. E-Journal Animal Science. Vol. (1): 1-9

2. I Made Nuriyasa; I Made Mastika, Eny Puspani. 2013. Local rabbit performance fed a diet containing different levels of metabolic energy. Majalah Ilmiah, Faculty of Animal Science, Udayana University, ISSN: 0853-8999 Vol.16: $12-17$

3. I Made Nuriyasa; I Made Mastika, I Gede Mahardika, I Gusti Agung I. Aryani. Energy and Protein Retention of Local Rabbit Housed in Different Cages. J. Biol. Chem.Research. ISSN: 2319-3077. Vol. 31 (2) :800-807.

4. I.Made Nuriyasa, I Made Mastika, G. Ayu Mayani Kristina Dewi. 2015. Performance of Local Rabbit (Lepus nigricollis) Fed Diets Containing Different Level of Fermented Coffee Pulp.

5. I Made Nuriyasa, Wayan Sayang Yupardhi, and Eny Puspani. 2016. Study on Growth Rate of Local Male Rabbit (Lepus nigricollis) Fed Different Energy Levels Diet and Sheltered in Different Density. J. Biol. Chem. Research. ISSN: 2319-3077. Vol.33, No 1: 449-452

6. I Gede Mahardhika Atmaja; I Made Nuriyasa, I Komang Budaarsa. 2016. The performance and carcass of local male rabbit (Lepus nigricollis) diet feed containing fermented grape wastes. J. Biol. Chem.Research. ISSN: 2319-3077. Vol.33, No. 1: 488-495.

7. I.M. Nuriyasa, S.C. Antonhino, I.G.M Rusdianta. 2017. Effect of Various Levels of Fermented Coffee Pulp on Performance of Duroc Pig Cross Bred (Sus vitatus) on eeksthe Age of 8-12 W. IJMAS. ISSN No: 2348-537X. Vol.4 No.6: 1 - 9.

8. I Made Nuriyasa, I Wayan Sayang Yupardhi, Budi Rahayu Tanama Putri, Dewi Ayu Warmadewi. 2017. Financial Trade Analysis of Local Rabbit Livestock Business That Use Coffee Skin Waste Product as Animal Fed. J. Biol. Chem.Research. ISSN: 2319-3077. Vol.34, No. 2: 454-459.

9. A.W. Puger, I.M. Nuriyasa. 2017. Performans and Carcass of Local Male Rabbit Fes of Basal Diet of Native Grasses and Different Levels Supplementation of MNB. IJMAS. ISSN No: 2348-537X. Vol 04.No 5: 53-60.

10. I Wayan Bagiarta, I Made Nuriyasa, Anthonius Wayan Puger. 2017. Nutrient diet digestibility of docal damale

Nuriyasa, I., Puspani, E., \& Yupardhi, W. (2018). Growth and Blood Profile of Lepus Nigricollis Fed Diet Fermented Coffee Skin in Different Levels. International Journal Of Life Sciences (IJLS), 2(1), 21-28. doi:10.29332/ijls.v2n1.83 
rabbit (Lepus nigricollis) offered Grass Field Supplemented Multi Nutrient Block (MNB). International Journal of Agriculture Innovations and Research. ISSN; 2319-1473. Vol. 5 No: 6: 921- 924.

Paper Presenter

Year Topic Committee

2014 Gusti Ayu Mayani Kristina Dewi, I Made Mudita, I Asia Future Conference, Diversity \&

Made Nuriyasa, I Wayan Wijana. The Effect of Harmony. Inna Grand Bali Beach Hotel\&

Biosuplement Probiotic Product For Slaughter Udayana University

Weight, Carcass Weight, Carcass Percentage,

Physical, Composition and Meat Quality of Bali Duck

2014 Gusti Ayu Mayani Kristina Dewi, I Made Mudita, I Made Nuriyasa, I Wayan Wijana. The Effect of Inclusion of Bio-Supplement as Probiotic in Diet on the Productivity of Bali Duck

Public Service Activity

\begin{tabular}{ll}
\hline \multicolumn{1}{c}{ Year } & \multicolumn{1}{c}{ Activity } \\
\hline 2012 & $\begin{array}{l}\text { The increase of rabbit productivity through microclimate revision of shelter and diet } \\
\text { quality at Riang Kelod Village, Tabanan Regency }\end{array}$ \\
\hline 2012 & $\begin{array}{l}\text { Introducing of rabbit diet in the form of pallet on rabbit farming at Dajan Peken Village, } \\
\text { Tabanan Regency }\end{array}$ \\
\hline 2013 & $\begin{array}{l}\text { The revision of goat farming management through chocolate fruit waste at Pupuan } \\
\text { District, Tabanan Regency }\end{array}$ \\
\hline 2014 & Introducing of coffee skin as rabbit fed at Riang Gede Village, Tabanan Regency. \\
\hline 2015 & Management revision of pig farming at Cau Belayu Village, Tabanan, Regency \\
\hline
\end{tabular}

I certify that all the information in Curriculum Vitae is true and if there is a mistake, I am willing to account for it. Indonesia, $5^{\text {th }}$ January 2018

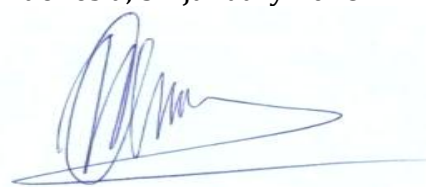

I Made Nuriyasa 